\title{
Rheological and Nutritional Properties and Sensory Evaluation of Bread Fortified with Natural Sources of Calcium
}

\author{
Amnah M. A. Alsuhaibani iD \\ Nutrition and Food Sciences Department, Princess Nourah Bint Abdulrahman University, Riyadh, Saudi Arabia \\ Correspondence should be addressed to Amnah M. A. Alsuhaibani; amalsuhaibani@pnu.edu.sa
}

Received 6 May 2018; Revised 8 July 2018; Accepted 14 August 2018; Published 17 September 2018

Academic Editor: Flora V. Romeo

Copyright $\odot 2018$ Amnah M. A. Alsuhaibani. This is an open access article distributed under the Creative Commons Attribution License, which permits unrestricted use, distribution, and reproduction in any medium, provided the original work is properly cited.

\begin{abstract}
By-products of oyster shell and egg shell are new candidates for use as calcium supplements. The effect of the fortification of bread with natural sources of calcium such as skim milk powder, egg shell powder, and oyster shell powder at levels of 10\%, 2\%, and 2\%, respectively, on the rheological, nutritional, and sensory properties was determined. Compared to the control bread, breads fortified with egg and oyster shells had a higher water absorption (\%), dough development time, dough stability, mixing time, heat of transition, and setback viscosity but a lower weakening index. Skim milk-fortified bread had the lowest levels of carbohydrates and energy of the bread formulations tested. Oyster shell-fortified bread showed significantly higher contents of protein, ash, fibre, and carbohydrates. Sensory evaluation revealed that the breads fortified with egg and oyster shells showed lower scores for odour and general acceptability compared with the control bread and the bread fortified with skim milk powder. Higher levels of minerals and amino acids except proline were estimated in the tested breads. These results indicate that the addition of natural sources of calcium to bread could positively impact its technological and nutritional properties.
\end{abstract}

\section{Introduction}

Calcium is required to build and maintain strong bones. The body mainly stores calcium in the bones and teeth, and a small amount is present in the muscle and the fluid between cells. Calcium is important for muscles and blood vessels to contract and expand, to secrete enzymes and hormones, and to send messages through the nervous system [1].

It is important that the dietary requirement of the body is met. Foods rich in calcium include dairy products (milk, cheese, and yogurt), leafy green vegetables, fish with soft bones (canned sardines and salmon), and calcium-enriched foods (breakfast cereals, fruit juices, and soy and rice drinks). The calcium requirement depends on age, and growing children and teenagers need more calcium than young adults. Lower levels of calcium in adults increase the risk for osteoporosis, and in children, low calcium levels can impact their potential adult height [2].

Diet is the best way to obtain calcium, but most common calcium supplements are calcium carbonate (40\% elemental calcium), calcium citrate ( $21 \%$ elemental calcium), calcium gluconate ( $9 \%$ elemental calcium), and calcium lactate ( $13 \%$ elemental calcium). Calcium, along with vitamin D, may have benefits beyond bone health and may protect against cancer, diabetes, and high blood pressure [3].

Bread is a staple food and is widely consumed by children and adults. It can be eaten as an ingredient in other cooking preparations or as a snack. Shape, colour, crust hardness, softness, and weight can influence the varieties of bread and their unique properties. Bread is rich in carbohydrates, fat, and energy but low in protein, minerals, and vitamins [4]. Thus, there has been increasing demand for different blends of flour including substituting wheat flour with other flours such as maize, sweet potato, and undefatted rice bran flours. Bread fortification is a health strategy and can impact more people without requiring them to change their existing consumption patterns. Bread fortification is an option for calcium daily intake supplementation to lower the risks of multiple deficiencies, and it is a cost-effective way to maintaining body stores of calcium [5].

The main objective of this research was to produce bread fortifying with different natural sources of calcium (skim 
milk powder or by-products such as wastes of egg shell and oyster shell) and to evaluate the chemical composition, rheological behaviour, and sensory attributes of these breads.

\section{Materials and Methods}

2.1. Sample Procurement. Wheat flour, sugar, butter, yeast, and salt were obtained from a local market in Riyadh, the Kingdom of Saudi Arabia. Eggs were purchased from a local market, while oyster shells were obtained from a fish restaurant.

2.2. Preparation of Egg Shell and Oyster Shell Powders. Eggs were washed first and then cracked to collect the egg shells. The egg shells with the inner coat and the oyster shells were boiled in water for ten minutes to kill bacteria. The shells were dried in an incubator at $37^{\circ} \mathrm{C}$ for ten minutes and then grounded to a fine powder using a mill.

\subsection{Formulations of Bread with Different Sources of Calcium.} The bread samples were prepared according to the method in [6]. Wheat flour was mixed with $10 \%$ skim milk powder, $2 \%$ egg shell powder, or $2 \%$ oyster shell powder, and this mixture was combined with the other ingredients as presented in Table 1 for the bread dough formulation. The dough was left for $55 \mathrm{~min}$ at $30^{\circ} \mathrm{C}$ and $40 \%$ relative humidity in a proofing cabinet, baked in an oven $\left(220^{\circ} \mathrm{C}\right.$ for $\left.10 \mathrm{~min}\right)$, and then cooled at room temperature before organoleptic evaluation. Other bread samples were frozen at $-18^{\circ} \mathrm{C}$. Three loaves of bread from each group were chemically analysed.

2.4. Rheological Properties. The rheological properties of the control sample and 3 blends were evaluated using farinograph tests and the Visco-Amylo-Graph. The farinograph test included water absorption (\%), dough development time (min), dough stability (min), dough weakening index, and mixing time, and these parameters were evaluated according to the method in [7]. Visco-Amylo-Graph tests were used to determine the heat of transition, maximum viscosity, temperature of maximum viscosity, breakdown viscosity, and setback viscosity, and these parameters were evaluated according to the method in [7]. Each sample was tested in two replications.

2.5. Sensory Evaluation. The control bread and breads fortified with skim milk and egg shell and oyster shell powders were cooled for two hours at room temperature $\left(25^{\circ} \mathrm{C}\right)$, cut into slices $(4 \times 3 \times 5 \mathrm{~cm})$, and served to twenty trained panelists for evaluation of general appearance, separation of layers, roundness, distribution of crumb, crust colour, taste, odour, and general acceptability using a hedonic scale.

2.6. Proximate Composition. The protein, fibre, fat ash, moisture, and carbohydrate contents of the calcium-fortified bread samples and $100 \%$ wheat bread (control) were
TABLE 1: Standard formula for bread preparation.

\begin{tabular}{lcc}
\hline Ingredient & Amount & $(\%)$ \\
\hline Wheat flour $72 \%$ & $100 \mathrm{~g}$ & 58.31 \\
Sugar & $2 \mathrm{~g}$ & 1.17 \\
Distilled water & $60 \mathrm{ml}$ & 34.98 \\
Dry yeast & $3.5 \mathrm{~g}$ & 2.04 \\
Salt & $2 \mathrm{~g}$ & 1.17 \\
Butter & $4 \mathrm{~g}$ & 2.33 \\
Total & 171.5 & 100 \\
\hline
\end{tabular}

determined using a standard analytical method [8]. The total carbohydrates were determined by difference (subtracting $100 \mathrm{~g}$ minus the sum of protein, ash, and fat), and the value is expressed in $\mathrm{g} / 100 \mathrm{~g}$.

2.7. Mineral Content. The calcium, iron, zinc, and phosphorus contents were estimated in the ash of the breads fortified with different sources of calcium by using atomic absorption spectrophotometry. The nutritional properties were calculated according to the method in [9] using the following equation:

nutritional fact $=$ mineral content/RDA $\times 10032$.

The RDAs for children (1-12 years) for calcium, zinc, iron, and phosphorus are $800,10,10$, and $700 \mathrm{mg} /$ day, respectively, according to the method in [10].

2.8. Staling Rate. The staling of breads was measured by evaluation of their alkaline water retention capacity by the method in [11].

2.9. Amino Acids, Protein Efficiency Ratio (PER), and Biological Value $(B V)$. The amino acids in the bread samples were determined by an amino acid analyser according to the method in [12]. PER and BV were calculated according to Alsmeyer et al. [13] and Mitchell [14] using the following equations:

$$
\begin{aligned}
\text { PER } & =0.684+0.456 \text { (leucine })-0.047 \text { (proline }) \\
\mathrm{BV} & =49.9+10.53 \text { PER38. }
\end{aligned}
$$

2.10. Statistical Analysis. The obtained data were subjected to analysis of variance (ANOVA) and Duncan's multiple range test to determine the significant differences, and data analyses were conducted using SPSS software version 16.0.

\section{Results}

Farinograph parameters of the dough behaviour of the control bread and breads fortified with skim milk and egg shell and oyster shell powders are illustrated in Table 2. Bread fortified with skim milk showed a slight increase in water absorption (\%), dough development time (min), dough stability (min), and mixing time and a decrease in dough weakening compared to the control bread. Breads 
TABLE 2: Farinograph parameters of the dough behaviour of the control bread and breads fortified with skim milk and egg shell and oyster shell powders.

\begin{tabular}{|c|c|c|c|c|c|}
\hline & $\begin{array}{c}\text { Water } \\
\text { absorption (\%) }\end{array}$ & $\begin{array}{c}\text { Dough development } \\
\text { time (min) }\end{array}$ & $\begin{array}{c}\text { Dough } \\
\text { stability }(\mathrm{min})\end{array}$ & $\begin{array}{l}\text { Dough weakening } \\
\text { index }(\mathrm{BU})\end{array}$ & $\begin{array}{c}\text { Mixing } \\
\text { time (min) }\end{array}$ \\
\hline Control bread & 58.35 & 1.1 & 2.4 & 120 & 2.1 \\
\hline Bread fortified with skim milk & 59.25 & 1.2 & 3.85 & 115 & 2.40 \\
\hline Bread fortified with egg shell & 60.84 & 1.4 & 4.31 & 110 & 3.2 \\
\hline Bread fortified with oyster shell & 61.75 & 1.5 & 4.51 & 111 & 3.30 \\
\hline
\end{tabular}

fortified with egg and oyster shells had higher water absorption (\%), dough development time (min), dough stability (min), and mixing time values and lower dough weakening index values compared to the control bread and bread fortified with skim milk powder. Visco-Amylo-Graph values of bread samples are presented in Table 3. Bread fortified with skim milk had lower values of heat of transition and breakdown viscosity and higher values of maximum viscosity, temperature of maximum viscosity, and setback viscosity. Bread fortified with egg shell had higher values of heat of transition, temperature of maximum viscosity, and setback viscosity. Bread fortified with oyster shell had higher values of heat of transition and setback viscosity compared to the control bread.

Sensory evaluation of breads fortified with skim milk and egg shell and oyster shell powders is presented in Table 4 . The sensory evaluation of the bread samples showed that breads fortified with skim milk have a score that it not significantly different from that of the control bread. Breads fortified with egg and oyster shells were not significantly different from the control bread and bread fortified with skim milk in their general appearance, separation of layers, roundness, distribution of crumb, crust colour, and taste but showed lower scores for odour and general acceptability.

Table 5 shows that the breads fortified with skim milk, egg shell, and oyster shell did not have significantly different moisture and fat contents, but their protein, ash, and fibre contents were significantly higher than those of the control bread. The moisture contents of the bread samples are similar, which may be due to fortification with skim milk and egg shell and oyster shell powders. Thus, the bread samples showed similar shelf stabilities at room temperature and under suitable environmental conditions. Skim milkfortified bread had the lowest levels of carbohydrates and energy. Egg shell-fortified bread showed similar values to oyster shell-fortified bread, but the oyster shell-fortified bread showed significantly higher levels of protein, ash, fibre, and carbohydrates compared to the control bread.

Table 6 illustrates that the mineral contents and the nutritional levels of the breads fortified with different sources of calcium were higher compared to the control bread. The recommended dietary allowances (RDAs) of Ca, $\mathrm{Fe}$, zinc, and $\mathrm{P}$ for children (1-12 years) are $800,10,10$, and $700 \mathrm{mg} /$ day, respectively. Skim milk-fortified bread had significantly higher levels of calcium, zinc, and phosphorus, which will provide children with $32.38,42.5$, and $58.57 \%$, respectively, of their daily requirements, while egg shelland oyster shell-fortified breads had significantly higher levels of calcium, iron, zinc, and phosphorus, which will provide children with $32.89,43.1,42$, and $60.50 \%$, respectively, of the RDAs from egg shell-fortified bread and $31.89,42.2,41.7$, and $59.38 \%$, respectively, of the RDAs from oyster shell-fortified bread.

The effect of fortification of breads with skim milk and egg shell and oyster shell powders on bread staling as evaluated by the alkaline water retention capacity is shown in Table 7. The control bread had a lower initial alkaline water retention capacity after 24 and $48 \mathrm{~h}$ of storage, while the bread fortified with egg shell had the highest values followed by bread fortified with oyster shell and then bread with skim milk, which indicated delayed staling and enhanced freshness can be achieved in breads fortified with skim milk and oyster shell.

The amino acid values in the protein ingredients are presented in Table 8. The results showed higher levels of the tested amino acids, total essential amino acids, total nonessential amino acids, and total amino acids except proline, which was lower in the breads fortified with skim milk and egg shell and oyster shell powders than in the control bread. Higher values were found in the bread fortified with skim milk, while lower values were found in bread fortified with oyster shell.

\section{Discussion}

Farinograph parameters of the dough behaviour are related to the composition. The main compound present in egg and oyster shells is calcium carbonate $\left(\mathrm{CaCO}_{3}\right)$, which is used as an additive in various foods including as a raw material in foods, medicines, and cosmetics and as a calcium source [15]. Chicken egg shell contains proteins as major constituents with small amounts of carbohydrates and lipids and contains approximately $95 \%$ calcium carbonate by weight, and $3.5 \%$ of the shell is an organic matrix formed from proteins, glycoprotein, and proteoglycans [16]. Oyster shell is composed of protein polysaccharides and also calcium carbonate with rare impurities. At room temperature, skim milk proteins are very soluble; however, heat treatment decreases the solubility of these proteins. The absorption of more water during mixing is a typical characteristic of composite starches [16]. The formation of a threedimensional network through forming bridges between the negatively charged proteins is enhanced by calcium enhancers. The gluten network restructuring by calcium produces stiffness and a more homogeneous matrix. The differences in the Visco-Amylo-Graph values of bread samples could be attributed to the different quantities and chemical compositions of the skim milk and oyster shell and egg shell powders. The consistency of the dough is greatly 
TABLE 3: Visco-Amylo-Graph parameters of the dough behaviour of the control bread and breads fortified with skim milk and egg shell and oyster shell powders.

\begin{tabular}{lccccc}
\hline & $\begin{array}{c}\text { Heat of } \\
\text { transition }\left({ }^{\circ} \mathrm{C}\right)\end{array}$ & $\begin{array}{c}\text { Maximum } \\
\text { viscosity }(\mathrm{BU})\end{array}$ & $\begin{array}{c}\text { Temperature of maximum } \\
\text { viscosity (BU) }\end{array}$ & $\begin{array}{c}\text { Breakdown } \\
\text { viscosity (BU) }\end{array}$ & $\begin{array}{c}\text { Setback } \\
\text { viscosity (BU) }\end{array}$ \\
\hline Control bread & 62 & 670 & 89.72 & 580 & 1350 \\
Bread fortified with skim milk & 61 & 675 & 90.11 & 574 & 1400 \\
Bread fortified with egg shell & 65 & 665 & 90.30 & 570 & 1390 \\
Bread fortified with oyster shell & 66 & 666 & 89.95 & 571 & 1392 \\
\hline
\end{tabular}

TABLE 4: Sensory evaluation of breads fortified with skim milk and egg shell and oyster shell powders.

\begin{tabular}{|c|c|c|c|c|c|c|c|c|}
\hline & $\begin{array}{c}\text { General } \\
\text { appearance } \\
(20)\end{array}$ & $\begin{array}{l}\text { Separation } \\
\text { of layer } \\
(20)\end{array}$ & $\begin{array}{l}\text { Roundness } \\
\text { (15) }\end{array}$ & $\begin{array}{c}\text { Distribution } \\
\text { of crumb } \\
(15)\end{array}$ & Crust colour & $\begin{array}{c}\text { Taste } \\
(10)\end{array}$ & $\begin{array}{l}\text { Odour } \\
(10)\end{array}$ & $\begin{array}{c}\text { General } \\
\text { acceptability } \\
(100)\end{array}$ \\
\hline Control bread & $19.55 \pm 1.66^{\mathrm{a}}$ & $19.15 \pm 1.30^{\mathrm{a}}$ & $14.55 \pm 1.11^{\mathrm{a}}$ & $14.60 \pm 1.25^{\mathrm{a}}$ & $9.51 \pm 0.34^{\mathrm{a}}$ & $9.40 \pm 1.22^{\mathrm{ab}}$ & $9.88 \pm 0.75^{\mathrm{a}}$ & $96.64 \pm 6.14^{\mathrm{a}}$ \\
\hline $\begin{array}{l}\text { Bread fortified } \\
\text { with skim milk }\end{array}$ & $19.10 \pm 1.55^{\mathrm{a}}$ & $19.25 \pm 1.09^{\mathrm{a}}$ & $14.75 \pm 1.13^{\mathrm{a}}$ & $14.45 \pm 1.430^{\mathrm{a}}$ & $9.50 \pm 0.57^{\mathrm{a}}$ & $10.00 \pm 1.38^{\mathrm{a}}$ & $9.80 \pm 0.77^{\mathrm{a}}$ & $96.85 \pm 6.11^{\mathrm{a}}$ \\
\hline $\begin{array}{l}\text { Bread fortified } \\
\text { with egg shell }\end{array}$ & $18.80 \pm 1.31^{\mathrm{ab}}$ & $18.85 \pm 1.43^{\mathrm{ab}}$ & $14.42 \pm 1.10^{\mathrm{a}}$ & $14.35 \pm 1.23^{\mathrm{a}}$ & $9.16 \pm 0.55^{\mathrm{a}}$ & $9.20 \pm 1.21^{\mathrm{ab}}$ & $8.99 \pm 0.59^{b}$ & $93.77 \pm 5.21^{\mathrm{b}}$ \\
\hline $\begin{array}{l}\text { Bread fortified } \\
\text { with oyster shell }\end{array}$ & $18.75 \pm 1.66^{\mathrm{ab}}$ & $18.80 \pm 1.59^{\mathrm{ab}}$ & $14.50 \pm 1.21^{\mathrm{a}}$ & $14.30 \pm 1.22^{\mathrm{a}}$ & $9.17 \pm 0.53^{\mathrm{a}}$ & $9.10 \pm 1.24^{\mathrm{ab}}$ & $8.95 \pm 0.65^{\mathrm{b}}$ & $93.57 \pm 5.29^{\mathrm{b}}$ \\
\hline
\end{tabular}

Values of three independent repeats $(n=3)$ are expressed as mean \pm SD. Values with different letters in each column are significant at $p<0.05$.

TABLE 5: Gross chemical composition of breads fortified with skim milk and egg shell and oyster shell powders (on dry weight bases g/100 g).

\begin{tabular}{|c|c|c|c|c|c|c|c|}
\hline & \multicolumn{7}{|c|}{ Chemical composition } \\
\hline & Moisture & Protein & Fat & Ash & Fibre & Carbohydrate & Energy \\
\hline Control bread & $32.75 \pm 3.68^{\mathrm{a}}$ & $7.80 \pm 0.33^{\mathrm{c}}$ & $2.08 \pm 0.12^{\mathrm{a}}$ & $1.90 \pm 0.10^{c}$ & $0.51 \pm 0.01^{\mathrm{c}}$ & $54.96 \pm 4.67^{\mathrm{b}}$ & $269.76 \pm 8.11^{\mathrm{a}}$ \\
\hline Bread fortified with skim milk & $34.66 \pm 4.11^{\mathrm{a}}$ & $13.17 \pm 1.20^{\mathrm{a}}$ & $2.19 \pm 0.17^{\mathrm{a}}$ & $3.19 \pm 0.30^{\mathrm{a}}$ & $0.55 \pm 0.03^{\mathrm{b}}$ & $46.24 \pm 4.35^{\mathrm{c}}$ & $257.35 \pm 7.88^{b c}$ \\
\hline Bread fortified with egg shell & $32.11 \pm 3.99^{\mathrm{a}}$ & $8.02 \pm 0.67^{\mathrm{b}}$ & $2.05 \pm 0.22^{\mathrm{a}}$ & $2.55 \pm 0.27^{\mathrm{b}}$ & $0.61 \pm 0.05^{\mathrm{a}}$ & $54.21 \pm 5.16^{\mathrm{a}}$ & $267.37 \pm 7.99^{\mathrm{ab}}$ \\
\hline Bread fortified with oyster shell & $32.17 \pm 4.04^{\mathrm{a}}$ & $7.99 \pm 0.87^{\mathrm{b}}$ & $2.03 \pm 0.34^{\mathrm{a}}$ & $2.45 \pm 0.35^{\mathrm{b}}$ & $0.63 \pm 0.08^{\mathrm{a}}$ & $54.73 \pm 4.90^{\mathrm{a}}$ & $269.15 \pm 8.07^{\mathrm{a}}$ \\
\hline
\end{tabular}

Values of three independent repeats $(n=3)$ are expressed as mean \pm SD. Values with different letters in the same column are significant at $p<0.05$.

TABLE 6: Calcium, iron, zinc, and phosphorus contents in the control bread and breads fortified with skim milk and egg shell and oyster shell powders.

\begin{tabular}{|c|c|c|c|c|c|c|c|c|}
\hline & \multicolumn{2}{|l|}{ Calcium } & \multicolumn{2}{|l|}{ Iron } & \multicolumn{2}{|l|}{ Zinc } & \multicolumn{2}{|c|}{ Phosphorus } \\
\hline & Content & NF & Content & NF & Content & NF & Content & NF \\
\hline Control bread & $95.20 \pm 3.62^{\mathrm{c}}$ & 11.9 & $3.58 \pm 0.29^{\mathrm{b}}$ & 35.8 & $2.30 \pm 0.29^{c}$ & 23.01 & $237.66 \pm 29.24^{\mathrm{c}}$ & 33.95 \\
\hline Bread fortified with skim milk & $259.11 \pm 18.15^{\mathrm{ab}}$ & 32.38 & $3.75 \pm 0.25^{\mathrm{ab}}$ & 37.5 & $4.25 \pm 0.39^{\mathrm{a}}$ & 42.5 & $440.56 \pm 45.16^{\mathrm{a}}$ & 58.57 \\
\hline Bread fortified with egg shell & $263.12 \pm 23.12^{\mathrm{a}}$ & 32.89 & $4.31 \pm 0.42^{\mathrm{a}}$ & 43.1 & $4.20 \pm 0.41^{\mathrm{a}}$ & 42 & $423.51 \pm 49.61^{\mathrm{ab}}$ & 60.50 \\
\hline Bread fortified with oyster shell & $255.13 \pm 21.19^{\mathrm{ab}}$ & 31.89 & $4.22 \pm 0.35^{\mathrm{a}}$ & 42.2 & $4.17 \pm 0.43^{\mathrm{ab}}$ & 41.7 & $415.70 \pm 48.77^{\mathrm{ab}}$ & 59.38 \\
\hline
\end{tabular}

Values of three independent repeats $(n=3)$ are expressed as mean \pm SD. Values with different letters in each column are significant at $p<0.05$. NF: nutritional fact.

TABLE 7: Alkaline water retention capacity of the control bread and breads fortified with skim milk and egg shell and oyster shell powders.

$$
\text { Alkaline water retention capacity (AWRC\%) }
$$

\begin{tabular}{lccccc} 
& At zero time & After 24h & Rate of decrease (\%) & After 48 h & Rate of decrease (\%) \\
\hline Control bread & $361.64 \pm 31.61^{\mathrm{bc}}$ & $259.39 \pm 15.16^{\mathrm{d}}$ & 28.27 & $211.16 \pm 8.66^{\mathrm{d}}$ & 47.61 \\
Bread fortified with skim milk & $405.86 \pm 44.43^{\mathrm{a}}$ & $325.91 \pm 21.14^{\mathrm{a}}$ & 19.69 & $277.29 \pm 19.70^{\mathrm{a}}$ & 31.67 \\
Bread fortified with egg shell & $387.55 \pm 30.71^{\mathrm{ab}}$ & $286.33 \pm 17.16^{\mathrm{bc}}$ & 26.11 & $228.47 \pm 10.24^{\mathrm{c}}$ & 41.04 \\
Bread fortified with oyster shell & $395.86 \pm 35.14^{\mathrm{a}}$ & $306.65 \pm 18.22^{\mathrm{ab}}$ & 22.53 & $248.43 \pm 14.65^{\mathrm{b}}$ & 37.24
\end{tabular}

Values of three independent repeats $(n=3)$ are expressed as mean \pm SD. Values with different letters in each column are significant at $p<0.05$.

dependent on the amount of water present or the hydration. When water adsorption is higher than $90 \%$, a very low consistency is generated during mixing. Starch changes during heating, and cooling affects the rheology of the bread.
This pattern is consistent with previous results reported in [17]. Skim milk powder contains proteins that could be successfully used in gluten-free recipes to obtain gluten-free bread with pleasant colour, taste, and flavour characteristics 
TABLE 8: Amino acid contents, PER, and BV of breads fortified with skim milk and egg shell and oyster shell powders.

\begin{tabular}{|c|c|c|c|c|}
\hline \multirow[b]{2}{*}{ Amino acid } & \multicolumn{4}{|c|}{ Bread } \\
\hline & $\begin{array}{c}\text { Bread control } \\
100 \% \mathrm{WF}\end{array}$ & $\begin{array}{l}\text { Bread fortified with } \\
\text { skim milk }\end{array}$ & $\begin{array}{l}\text { Bread fortified with } \\
\text { egg shell }\end{array}$ & $\begin{array}{c}\text { Bread fortified with } \\
\text { oyster shell }\end{array}$ \\
\hline Isoleucine & 1.92 & 3.71 & 2.11 & 2.45 \\
\hline Leucine & 4.43 & 6.85 & 5.99 & 5.85 \\
\hline Lysine & 1.56 & 2.66 & 1.98 & 1.79 \\
\hline Threonine & 2.15 & 3.40 & 2.95 & 2.88 \\
\hline Tryptophan & 0.79 & 1.29 & 0.89 & 0.87 \\
\hline Valine & 2.55 & 3.69 & 2.88 & 2.70 \\
\hline Methionine & 1.30 & 1.95 & 1.49 & 1.46 \\
\hline Phenylalanine & 4.11 & 6.81 & 4.90 & 4.88 \\
\hline Histidine & 1.84 & 3.77 & 2.33 & 2.20 \\
\hline Arginine & 3.22 & 5.33 & 4.11 & 4.27 \\
\hline Tyrosine & 2.80 & 4.09 & 3.99 & 3.77 \\
\hline Cystine & 1.91 & 2.96 & 2.01 & 2.17 \\
\hline Proline & 12.89 & 8.99 & 9.77 & 9.81 \\
\hline Alanine & 2.21 & 4.27 & 3.66 & 3.51 \\
\hline Glutamic acid & 27.99 & 35.96 & 30.11 & 29.66 \\
\hline Glycine & 4.78 & 7.86 & 5.14 & 5.18 \\
\hline Aspartic acid & 4.67 & 6.59 & 4.96 & 4.95 \\
\hline Serine & 6.60 & 7.77 & 6.95 & 6.88 \\
\hline Total essential amino acids & 18.81 & 30.63 & 23.20 & 22.88 \\
\hline Total nonessential amino acids & 68.91 & 87.59 & 73.03 & 72.4 \\
\hline Total amino acids & 87.72 & 110.45 & 96.23 & 95.28 \\
\hline BV & 71.99 & 85.49 & 80.96 & 80.33 \\
\hline PER & 2.09 & 3.38 & 2.95 & 2.89 \\
\hline
\end{tabular}

and improved technological and nutritional properties. Considerable effort has been spent studying how flour components affect the rheology of flour-water dough. Gluten protein consists of gliadin and glutenin proteins. Gluten plays multiple roles in the majority of baked products because of its unique viscoelastic properties. The gliadins contribute primarily to the viscous behaviour of a viscoelastic dough. The glutenin proteins are responsible for the elastic component of a dough's behaviour. During processing, gluten plays an important role in emulsification, viscoelasticity, cohesiveness, and elasticity. Moroni et al. [18] reported that the sourdough technology could be used to improve the quality of gluten-free bread. In addition, a casein-based ingredient fortified with calcium could form a gel network to resemble the gluten network.

Sensory evaluation results were similar to the results of Olapade [19] who reported that bread loaves made with enriched composite flour with up to $10 \%$ cowpea flour were acceptable to panelists. Ranhotra et al. [20] found that the addition of calcium at $211,446,924$, and $1412 \mathrm{mg} / 100 \mathrm{~g}$ to breads had no adverse effect on the sensory properties of those breads. The addition of skim milk powders combined with an optimal amount of water resulted in an increase in loaf volume and a decrease in crust and crumb hardness, and the generated bread was rich in proteins with good acceptability scores in the sensory evaluation.

Bread is a staple food in the diets of many people around the world, and it contains macro- and micronutrients such as carbohydrates, protein, fibre, vitamins, and minerals. The gross composition of the bread samples was mainly dependent on the constituents of the skim milk, egg shell, and oyster shell. The obtained results were consistent with the results for bread enriched with moringa seed flour and bread produced from blends of maize, wheat, and orange-fleshed sweet potato flour documented by Bibiana et al. [21] and Fagundes et al. [22]. The obtained results were consistent with the results of Odunlade et al. [23], who reported increased levels of protein (9.50 to $13.93 \%)$, fibre (1.81 to $4.00 \%)$, and ash (1.05 to $2.38 \%)$ when vegetable powders were added to wheat bread during preparation of dough.

Minerals are needed for the proper functioning of tissues and organs, and the bioavailability of minerals depends on the type of product, the degree of purification from raw food, and the processing techniques used; thus, the intake of macro- and micronutrients depends on the diet as confirmed by Kim [24]. The obtained results were consistent with the results of Regula et al. [25] who reported that the addition of milk powder significantly influenced the content and bioavailability of calcium, magnesium, iron, zinc, and copper, and the bioavailability of these minerals increased when the bread was enriched. Thus, these types of breads could be used to treat mineral deficiency-related diseases because minerals play an important role in the proper functioning of tissues and organs as reported by Kim [24]. Additionally, Brun et al. [26] reported that milk has a good bioavailability of calcium (approximately 30 to 35\%) and meets the recommendations for calcium, while a single egg shell contains $2.07 \pm 0.18 \mathrm{~g}$ of $\mathrm{Ca}$. The best way is to add chicken egg shell and oyster shell powders to bread, pizza, or spaghetti as the addition causes only small changes in general acceptability and no changes in general appearance. 
These results of the alkaline water retention capacity are consistent with those reported in [27]. Caseins in skim milk contain regions of high, medium, and low hydrophobicity. Gluten-free doughs containing dairy proteins had very low consistencies during the mixing stage, and their consistencies decreased during the heating and cooling stages. Bread fortified with egg shell had the lowest values of isoleucine, arginine, cystine, proline, and glycine. The highest values of PER and BV were recorded in the bread fortified with skim milk followed by the bread fortified with egg shell and then the bread fortified with oyster shell, and the control bread had the lowest values. These results were consistent with those reported in [28]. Skim milk increases the nutritional value of bakery products because of the milk proteins and essential amino acids, such as lysine, methionine, and tryptophan [29], so skim milk positively impacts breads' technological and nutritional properties.

\section{Conclusion}

In conclusion, the fortification of bread with natural sources of calcium, such as skim milk powder and waste products like oyster shell and egg shell powders, was found to improve the rheological characteristics of dough and the quality and nutritional properties compared to the control bread. However, the addition of oyster shell and egg shell powders decreases significantly the general acceptability compared to the control bread. The fortification of bread with natural sources of calcium is therefore recommended. Further research is necessary to explore different methods of utilising waste products and to determine the effects of the fortification of bakery products with different levels of calcium on increasing the quality of the products.

\section{Data Availability}

The data used to support the findings of this study are available from the corresponding author upon request.

\section{Conflicts of Interest}

The author declares that there are no conflicts of interest.

\section{Acknowledgments}

The author expresses her profound gratitude to Princess Nourah Bint Abdulrahman University for its moral support in completing this research paper.

\section{References}

[1] C. Gennari, "Calcium and vitamin D nutrition and bone disease of the elderly," Public Health Nutrition, vol. 4, no. 2b, pp. 547-559, 2001.

[2] S. A. Lanham-New, "Importance of calcium, vitamin D and vitamin $\mathrm{K}$ for osteoporosis prevention and treatment," Proceedings of the Nutrition Society, vol. 67, no. 2, pp. 163-176, 2008.

[3] K. D. Cashman, "Calcium and vitamin D," Novartis Foundation Symposia, vol. 282, pp. 123-138, 2007.
[4] M. O. Ameh, D. I. Gernah, and B. D. Igbabul, "Physicochemical and sensory evaluation of wheat bread supplemented with stabilized undefatted rice bran," Food and Nutrition Sciences, vol. 4, pp. 43-48, 2013.

[5] J. K. Das, R. A. Salam, R. Kumar, and Z. A. Bhutta, "Micronutrient fortification of food and its impact on woman and child health: a systematic review," Systematic Reviews, vol. 2, p. 67, 2013.

[6] K. A. Long, Acceptance of Bread with Partial Replacement of Wheat Bread Flour by Potato Products in Selected Regions of the USSR and USA, Doctoral Dissertation, Virginia Tech, Blacksburg, VA, USA, 1991.

[7] N. W. Tietz, Clinical Guide to Laboratory Tests, W. B. Saunders, Philadelphia, PA, USA, 3rd edition, 1995.

[8] AOAC, Official Methods of Analysis, Association of Official Analytical Chemists, Washington, DC, USA, 2007.

[9] M. D. EL-Nahal and H. N. Assem, "Studies on Chufa flour and germinated chufa used in sweet biscuits for slim people," Food Technology Research Insitute, Egyptian Journal of Nutrition, vol. 20, pp. 173-194, 2005.

[10] A. H. Lichtenstein, L. J. Appel, M. Brands et al., "Diet and lifestyle recommendations revision 2006: a scientific statement from the American Heart Association Nutrition Committee," Circulation, vol. 114, pp. 82-96, 2006.

[11] J. S. Kitterman and G. L. Rubenthaler, "Assessing the quality of early generation wheat selection with the micro AWRC test," Journal of Cereal Science, vol. 16, pp. 313-316, 1971.

[12] N. Ibrahim and W. El-Eraqy, "Protein content and amino acid composition of Nelumbo nucifera seeds and its evaluation as hypoglycaemic agent," Egyptian Journal of Pharmaceutical Sciences, vol. 37, pp. 635-641, 1996.

[13] R. H. Alsmeyer, A. E. Cunningham, and M. L. Happich, "Equations predict PER from amino acid analysis," Food Technology, vol. 28, pp. 34-40, 1974.

[14] H. Mitchell and R. J. Block, "Some relationships between the amino acid contents of proteins and their nutritive values for the rat," Journal of Biological Chemistry, vol. 163, pp. 599-620, 1946.

[15] M. G. Cho, S. M. Bae, and J. Y. Jeong, "Egg shell and oyster shell powder as alternatives for synthetic phosphate: effects on the quality of cooked ground pork products," Korean Journal for Food Science of Animal Resources, vol. 37, no. 4, pp. 571-578, 2017.

[16] W. Daengprok, W. Garnjanagoonchorn, O. Naivikul, P. Pornsinlpatip, K. Issigonis, and Y. Mine, "Chicken eggshell matrix proteins enhance calcium transport in the human intestinal epithelial cells, Caco-2," Journal of Agricultural and Food Chemistry, vol. 51, no. 20, pp. 6056-6061, 2003.

[17] C. Marco and C. M. Rosell, "Breadmaking performance of protein enriched, gluten-free breads," European Food Research and Technology, vol. 227, pp. 1205-1213, 2008.

[18] A. V. Moroni, F. Dal Bello, and E. K. Arendt, "Sourdough in gluten-free bread-making: an ancient technology to solve a novel issue?," Food Microbiology, vol. 26, pp. 676-684, 2009.

[19] A. A. Olapade and O. B. Oluwole, "Bread making potential of composite flour of wheat-acha (Digitaria exilis staph) enriched with cowpea (Vigna unguiculata L. walp) flour," Nigerian Food Journal, vol. 31, no. 1, pp. 6-12, 2013.

[20] G. S. Ranhotra, J. A. Gelroth, and S. D. Leinen, "Utilization of calcium in breads highly fortified with calcium as calcium carbonate or as dairy calcium," Cereal Chemistry Journal, vol. 77, no. 3, pp. 293-296, 2000. 
[21] I. Bibiana, N. Grace, and A. Julius, "Quality evaluation of composite bread produced from wheat, maize and orange fleshed sweet potato flours," American Journal of Food Science and Technology, vol. 2, no. 4, pp. 109-115, 2014.

[22] G. A. Fagundes, M. Rocha, and M. M. Salas-Mellado, "Improvement of protein content and effect on technological properties of wheat bread with the addition by cobia (Rachycentron canadum)," Food Research, vol. 2, no. 3, pp. 221-227, 2018.

[23] T. V. Odunlade, A. A. Famuwagun, K. A. Taiwo, S. O. Gbadamosi, D. J. Oyedele, and O. C. Adebooye, "Chemical composition and quality characteristics of wheat bread supplemented with leafy vegetable powders," Journal of Food Quality, vol. 2017, pp. 1-7, 2017.

[24] M.-H. Kim and M.-K. Choi, "Seven dietary minerals (Ca, P, $\mathrm{Mg}, \mathrm{Fe}, \mathrm{Zn}, \mathrm{Cu}$, and $\mathrm{Mn}$ ) and their relationship with blood pressure and blood lipids in healthy adults with self-selected diet," Biological Trace Element Research, vol. 153, no. 1-3, pp. 69-75, 2013.

[25] J. Regula, A. Cerba, J. Suliburska, and A. A. Tinkov, "In vitro bioavailability of calcium, magnesium, iron, zinc, and copper from gluten-free breads supplemented with natural additives," Biological Trace Element Research, vol. 182, no. 1, pp. 140-146, 2018.

[26] L. R. Brun, M. Lupo, D. A. Delorenzi, V. E. Di Loreto, and A. Rigalli, "Chicken eggshell as suitable calcium source at home," International Journal of Food Sciences and Nutrition, vol. 64, no. 6, pp. 740-743, 2013.

[27] M. Jekle and T. Becker, "Effects of acidification, sodium chloride, and moisture levels on wheat dough: II. Modeling of bread texture and staling kinetics," Food Biophysics, vol. 7, no. 3, pp. 200-208, 2012.

[28] D. Knežević, D. Mihajlović, and D. Kondić, "Contents of amino acids in grains of different bread wheat genotypes," Agroznanje, vol. 14, no. 3, pp. 431-439, 2013.

[29] M. H. B. Nunes, L. A. M. Ryan, and E. K. Arendt, "Effect of low lactose dairy powder addition on the properties of glutenfree batters and bread quality," European Food Research and Technology, vol. 229, pp. 31-41, 2009. 


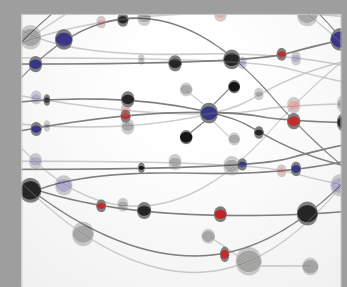

The Scientific World Journal
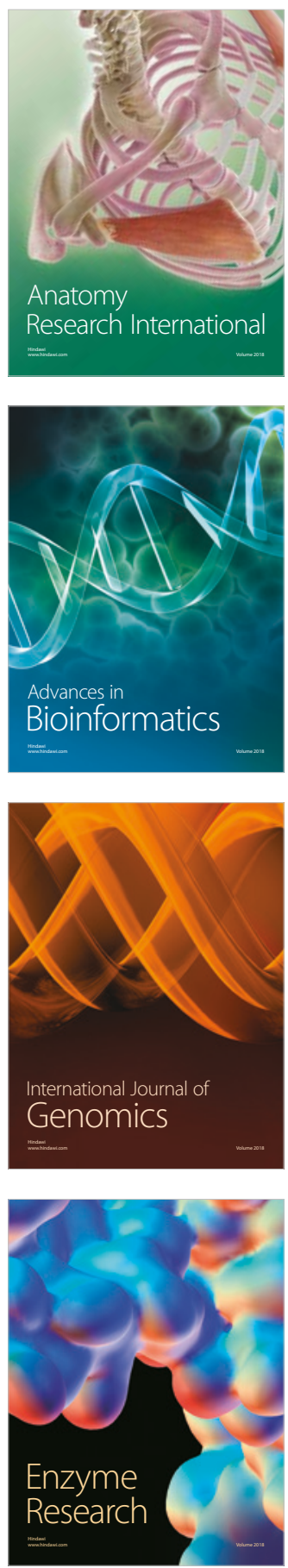
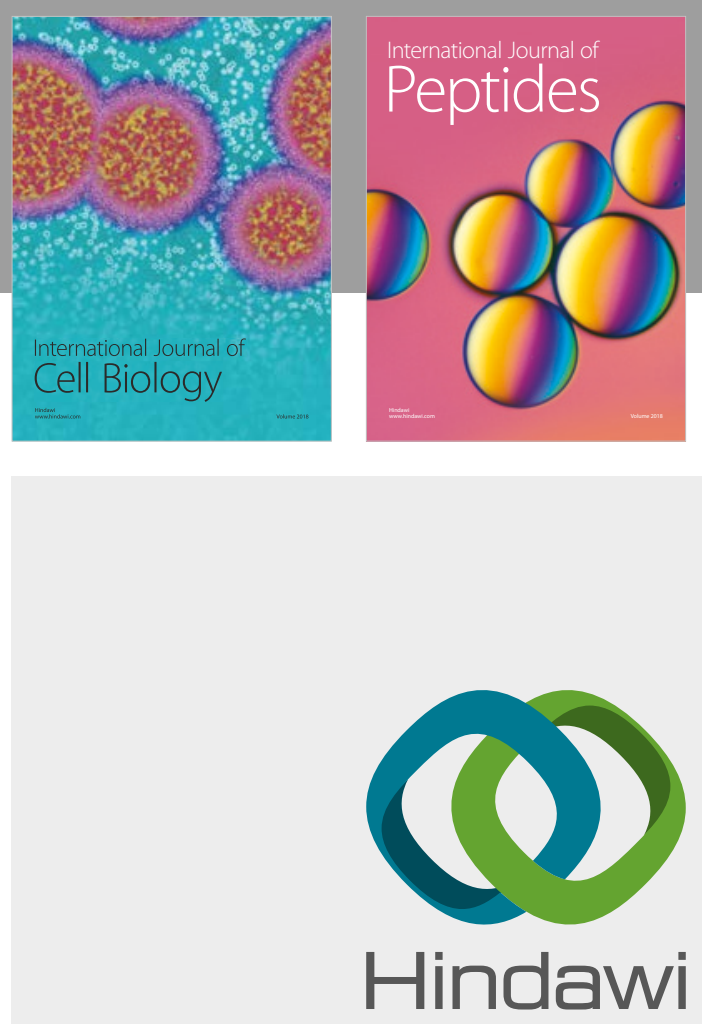

Submit your manuscripts at

www.hindawi.com
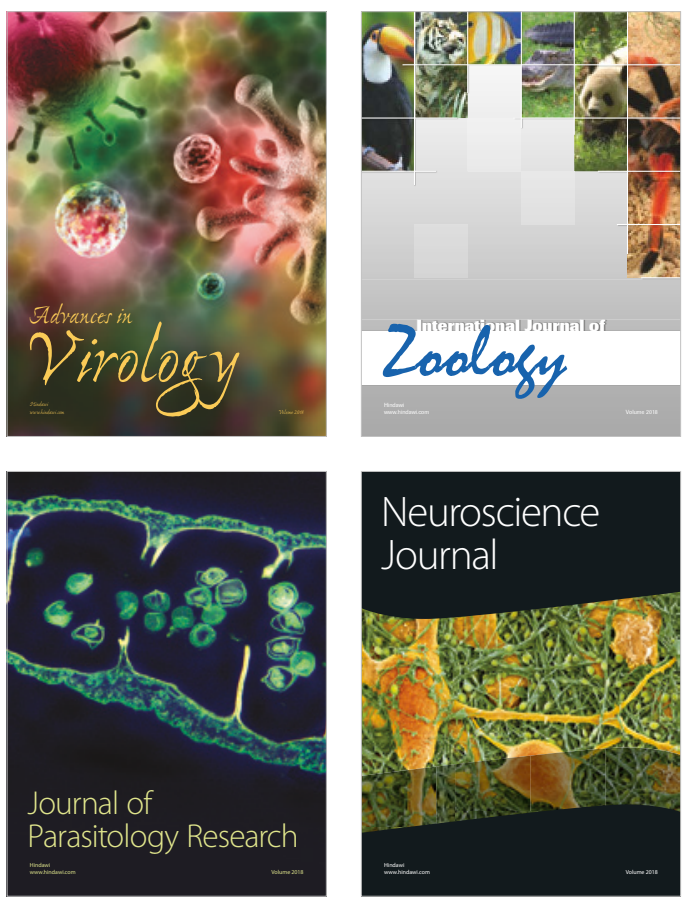
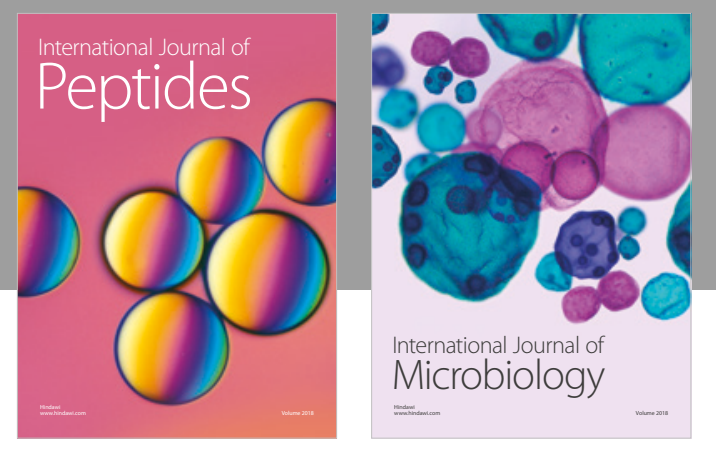

nternational Journal of Microbiology
Journal of
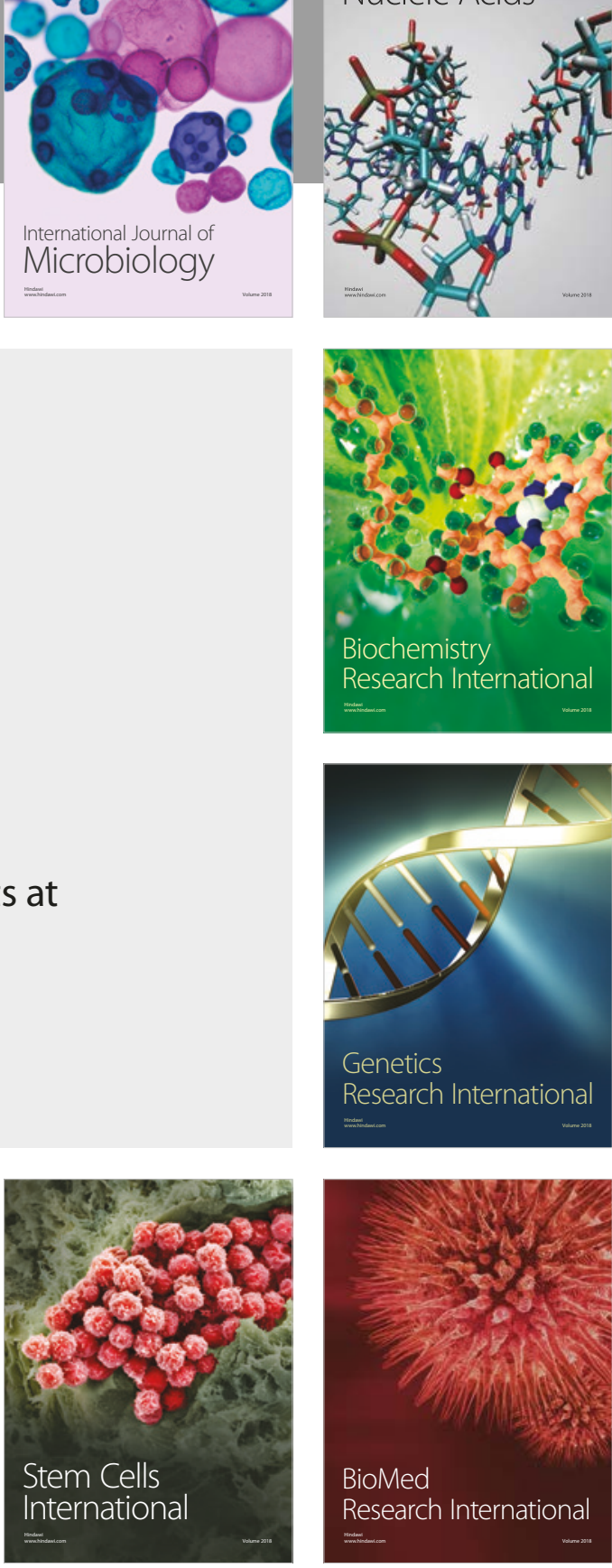
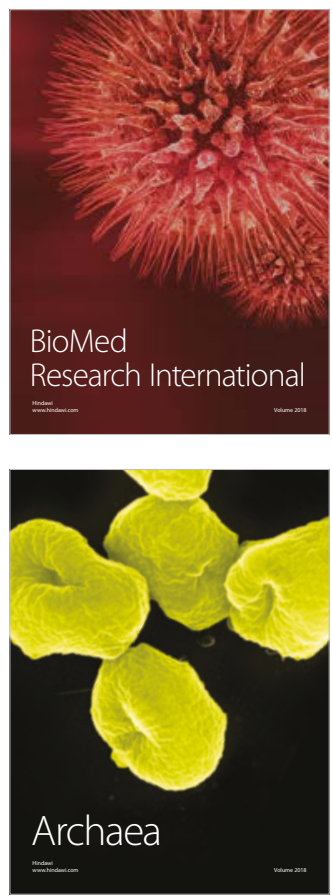